\title{
THE INTEREST OF CLASSIC PIANO STUDENTS IN SEMARANG MUSIC COURSE
}

\author{
Kusrina Widjajantie ${ }^{\varpi}$ \\ Fakultas Bahasa Dan Seni, Universitas Negeri Semarang, Indonesia \\ R. Agustinus Eka Arum Nugroho \\ Fakultas Ilmu Pendidikan, Universitas Negeri Semarang, Indonesia
}

Info Artikel

Submitted : May, 2021

Revised : May, 2021

Accepted : June, 2021

Keywords:

Piano Learning, Piano,

Music Course
Abstract

The community is very enthusiastic about welcoming music education institutions. There are many people's desire to learn music, especially piano, but not all students have the same interest in learning music. In this case the researchers limited the classical piano participants, with ages 4-6 years. Based on observations, the classical piano learning process has a very detailed learning stage, so that students experience boredom in learning. Seeing this fact, the researcher wanted to know the students' interest in learning classical piano in the Music course in Semarang. The benefit of this research is to know the students' interest in learning classical piano. So that these results can be used for the development of methods, materials, strategies, and media in classical piano learning. The development of this learning component has a beneficial impact on the owners of educational institutions, teachers and students.

The result of the discussion is that interest has a great influence on students in learning, because if the material and learning methods are not in accordance with their interests, students will not learn as well as possible, because there is no attraction for them. For students aged 4-6 years, students cannot achieve learning goals just because of interest, but other psychological factors such as intelligence, attention, talent, maturity, readiness, especially motivation that can help return the initial interest, namely learning the piano. Motivation from the closest people, usually parents play an important role in the growth of interest. 


\section{INTRODUCTIONS}

The rapid development of this era of globalization affects all aspects of life, especially in the field of music. Music is the result of human work that can be heard by both the audience and its presentation in the form of vocals and instrumentals. Along with the times, music is increasingly in demand by people around the world, from children to parents. Many people think that art must be fostered and developed in society, because it has an important role in efforts to fulfill the needs of human life. One of them is the number of music courses that have sprung up in the city of Semarang, which aims to improve music skills in the community, as well as improve human resources. The purpose of human resources is to improve skills in the field of music in students studying in the course. Then on the teacher, namely honing professionalism in terms of music, having experience teaching students with diverse characters. Of course, students and teachers have their own goals to achieve success. The success of learning music is influenced by many factors, one of which is interest. The existence of interest in children, the learning process can be carried out well. Then furthermore, if the music learning process is carried out well, we can find out how far the level of music education in Indonesia is. An interest can be expressed through a statement that shows that students prefer one thing over another. Students who have an interest in certain subjects tend to give greater attention to these subjects. (Slameto, $2003 ; 180)$. In fact, the results of the researcher's observations showed that students who were initially interested in piano, but 2 to 3 months of students were bored and wanted to change musical instruments, some even wanted to leave the course. There is a need for improvements to the components of piano learning, both from the teacher's knowledge of child psychology, the preparation of materials, methods, strategies, and evaluation of teaching, as well as the influence of the learning environment.

Halamik defined music learning has several components, including several elements including learning elements, namely educational objectives, students, educators, learning materials or materials, approaches or methods, media or tools, learning resources and evaluations (Dolong, 2016). These elements are in a complete system and mutually support each other, to produce the desired goals, so as to create quality learning.

\section{METHODS}

The research subjects were classical piano students in Semarang, then assisted with data from parents, tutors, and administrative staff at the course. This study uses a qualitative descriptive method, with the consideration that the data obtained is more in-depth. This research is viewed from the perspective of child psychology, which will analyze children's interest in learning the piano. The data collection technique used is the method of observation, interviews, and documentation. While the analysis technique consists of data reduction, data presentation, and drawing conclusions/verification (Miles. M, B., \& Huberman, 1994).

\section{RESULTS AND DISCUSSION}

Based on the results of interviews conducted by researchers to student resource persons, it was found that most of the students' interests in learning music were different, although there were students who had the same interest in learning music. However, over time, students' interests change because they find it difficult or feel bored with the learning they are experiencing.

Interest has a big influence on learning, because if the subject matter being studied is not in accordance with the interests of students, students will not learn as well as possible, because there is no attraction for them. Students become reluctant to learn, and do not get satisfaction from the lesson. Learning materials that students are interested in will be easier to learn, keep in mind, and can add to student learning activities. Developing an interest in something is basically helping students see how the relationship between the material they are expected to learn and themselves as individuals is. This process means showing students how certain knowledge or skills will affect them, serve their goals, satisfy their needs. If students realize that learning is a tool to achieve some goals that they consider important, and if students see that the results of their learning experiences will bring progress to themselves, they will most likely be interested.

The interest that students have in learning music begins to decline, if the expected desires are not achieved. To find out the students' interests, the researchers referred to observations and interviews with students and parents, teachers and admin 
staff of music courses in Semarang. In observations and interviews, the researchers found the fact that the interests of students and parents of music course participants at the course were different.

The following are the results of research conducted by researchers at a music course in Semarang, the number of classical piano students is 20 students, $25 \%$ of students are $4-6$ years old, $50 \%$ of students are $7-15$ years old, $15 \%$ of students are $16-18$ years old, $10 \%$ of students 40 years and over.

First, the researcher interviewed a student named Sheila, "I'm happy to learn the piano, then Sheila replied, "I'm happy Sis". At the beginning of the study, Sheila seemed enthusiastic and followed the course, pleased with the state of the environment such as the friendliness of the administrative staff and their teachers. The new environment and new musical instruments made students feel at home in class for a long time. As Slameto argues that interest is always accompanied by feelings of pleasure, and satisfaction is obtained from it (Slameto, 2003).

According to Reber, interest is not a popular term in psychology, because it relies a lot on other internal factors such as: concentration of attention, curiosity, motivation and needs. However, regardless of popular issues or not, interest as understood and used by people so far can affect the quality of student achievement in certain fields of study (Syah, 2014). For example, a student who has a great interest in learning the piano. Then the student will focus more attention than other students. Then, because of the intensive attention to the piano material, which allows the student to study harder, and finally achieve the desired achievement. Teachers in this regard should try to arouse students' interest in mastering the knowledge contained in learning the piano, in more or less the same way with tips for building a positive attitude.

According to observations, interest for children aged 4-6 years does not always last long or does not match the reality. This means that children are always changing their desires. So the interest of students aged 4-6 years is less able to be a benchmark, meaning that at the beginning the student is very interested, but 1-3 months later they are starting to become less enthusiastic. So it takes motivation from parents or those closest to them. Slameto's opinion which says that interest is part of the psychological factors that affect learning. Other psychological factors are intelligence, attention, talent, motives, maturity and readiness (Slameto, 2003). So in learning, psychological factors are related to each other. As in the case of students aged 4-6 years who are learning the piano, initially they are very interested in learning the piano, but after 2 months, these students need motivation from their parents and close people. After 2 months the students are interested in other activities, their physical condition is sleepy or tired, and so on so that the students do not seem to focus on learning the piano. Things like this need encouragement or motivation to get back to learning the piano.

Interest as a psychological aspect is influenced by several factors, both internal (internal) and external (external). Seen from within students, interests are influenced by ideals, satisfaction, needs, talents and habits. Meanwhile, when viewed from external factors, interest is not permanent but can change according to environmental conditions. External factors can be in the form of completeness of facilities and infrastructure, association with parents and public perception of an object and socio-cultural background (Slameto, 2003). The influencing factors above can be overcome by the teacher by: 1) presenting material that is designed in a systematic, more practical and more artistic way, 2) providing stimulation to students to pay high attention to the field of study being taught, 3) develop regular habits, 4) improve the physical condition of students, 5) maintain the ideals and aspirations of students, 6) provide adequate supporting facilities.

Interest is part of the psychological factors that affect learning. Other psychological factors are intelligence, attention, talent, motives, maturity and readiness. In learning the piano there are two lessons, namely classical piano learning and pop piano learning.

Classical piano learning discusses piano playing which begins with understanding music theory, notation forms or symbols, playing techniques and interpreting a song according to the composer. So that in studying classical piano, we always study the songs of previous composers according to the periods, including: 1) the baroque period, 2) the classical period, 3) the romantic period, 4) the modern period. Each era has characteristics due to environmental conditions, the condition of musical instruments at that time, and of course the creativity of composers at that time. In reality, visualization or classical piano scores and how to play them are more complicated and complex. In enjoying and living classical piano songs 
according to previous researchers, it is not easy, only a few people really understand the meaning of the song. Learning classical piano for beginners is not as complicated as what was described above. Classical piano lessons are often referred to as basic piano, meaning that piano lessons starting from the basics, namely adjusting the fingers on the keys on the piano, such as pressing a black key with all five fingers of both the right and left fingers without knowing what note it is, give the name finger with the designation of finger 1 , finger 2 and so on, recognize the beat, recognize the place of the tone, then recognize the name of the tone which usually uses the common notation name, namely c, d, e, f, g, and then $a, b$.

According to Yukhe (piano teacher), that finger formation is very important for beginners, so that the fingers look more skilled and there are no finger defects for finger movement at a higher level. Classical piano learning can build students' emotions, because piano learning for beginners is not only about playing the piano, but the teacher is more on the approach of child psychology. According to Mrs. Yukhe that there are several approaches used in introducing piano learning, with the basis of playing, namely by singing. This means that the teacher sings while playing the piano, so that students are happy with the piano musical instrument. Second, the teacher gives color to each song, even drawing with the colors that students like. Third, the teacher teaches students with cheerful movements, such as shaking his head, clapping his hands, smiling. Fourth, the teacher gives several themed songs and even those themes are in the form of pictures, then the teacher tells stories or storytelling, so students always want to ask the stories which end with piano playing. Finally, the teacher always brings rewards or prizes if students can play some of the songs that have been taught. The songs given in the course are designed so that children can be interested in playing the piano.

While learning piano pop according to Mulyana is learning a popular song, by imitating existing popular songs, namely in the form of melody and accompaniment. Usually playing songs with easy listening melodies or songs that we already know, without us translating one by one notation that we will play. Initially students were only given instructions for writing simple tone symbols, both musical notes and numerical notes on the melody (right hand), while the left hand was given chord symbols. Learning piano pop is very fun, because we learn songs we know and will memorize them over time.
Nuryanti argues learning the piano is very liked by children because it is easy to play. Starting from the interests of children who are interested in playing the piano with the songs they like, thereby creating a sense of satisfaction in themselves, then they will develop well if they are aware and eager to develop themselves and make themselves superior in playing the piano, even though the potential of children is very diverse (Mahargiyanti, 2017). According to Natalia (a classical piano teacher in Semarang), if this interest begins with innate potential such as good talent and intellectual ability and is cultivated diligently, seriously in a long process, is always honed continuously and is in an environment that she is interested in, the child will become reliable in the field he is engaged in, namely the piano.

It can be concluded that at the age of 4-6 years, students cannot achieve their goals only because of interest, but other psychological factors such as intelligence, attention, talent, maturity, readiness, especially motivation that can help return their initial interest, namely learning piano. Sometimes students at that age cannot return to their initial interests, because 1) students are interested in how easy the piano is to play, 2) join their friends, 3) the friendliness of the teacher and admin staff so that students decide to learn piano, 4) students just talk.

Ages 4-6 years are students can not focus on one object, but move around or called the explorer period. At first he seemed interested, then after a few weeks he became disinterested. This age is the time when students still need other people, it can be parents, caregivers, assistants, teachers or other closest people. These students cannot be released on their own, they still need guidance, even though at that age students tend to be selfish, and seem independent and feel they can help others. Piano learning for students is not only the task of the piano teacher, but also the task of parents (Megawati, 2016).

Interest at the age of 4-6 years is a period filled with play, so learning anything is always coupled with playing. In piano lessons, the material prepared has also been adapted to the character of the students of that age. Starting from learning the beats of both each bar and each note, the place of the note, the name of the note and the finger number. This piano handbook will describe the essence of piano learning, such as learning beats, both for each measure and for each note, note places, note names and finger numbers in the form of songs. Through this piano handbook, students' interest in learning the piano will be channeled. 
Although full of different emotional dynamics every week.

\section{CONCLUSION}

Students cannot achieve goals only because of interest, but other psychological factors such as intelligence, attention, talent, maturity, readiness, especially motivation that can help return to initial interest, namely learning the piano. Sometimes students at that age cannot return to their initial interests, because 1) students are interested in how easy the piano is to play, 2) join their friends, 3) the friendliness of the teacher and admin staff so that students decide to learn piano, 4) students just talk.

Interest has a big influence on learning, because if the subject matter being studied is not in accordance with the interests of students, students will not learn as well as possible, because there is no attraction for them.
Dolong, J. (2016). Teknik Analisis dalam Komponen Pembelajaran. Jurnal UIN Alauddin, 5(2).

Mahargiyanti, M. (2017). Pengembangan Bakat Dan Minat Melalui Kegiatan Ekstrakurikuler Pramuka Pada Siswa MTs Muhammadiyah 07 Purbalingga. IAIN Purwokerto.

Megawati, H. (2016). Hitam Putih Piano. Pustaka Muda.

Miles. M, B., \& Huberman, A. M. (1994). Qualitative Data Analysis (2nd ed.) (2nd ed.). Sage Publications.

Slameto. (2003). Belajar dan Faktor-faktor yang Mempengaruhinya. Rineka Cipta.

Syah, M. (2014). Psikologi Pendiikan dengan Pendekatan Baru. Remaja Rosdakarya.

\section{REFERENCES}

